\title{
PENINGKATAN KEINGINTAHUAN MASYARAKAT MENGENAI PENGGUNAAN OBAT YANG BAIK DAN BENAR
}

\author{
Sara Nurmala, Rini Ambarwati, dan Emy Oktaviani \\ Program Studi Farmasi Fakultas Matematika dan Ilmu Pengetahuan Alam, Universitas Pakuan \\ Jl. Pakuan PO Box 452 Bogor 16143 Jawa Barat Indonesia \\ E-mail: sara.nurmala@gmail.com
}

\begin{abstract}
ABSTRAK. Keinginan masyarakat untuk mengetahui cara penggunaan obat yang baik dan benar saat ini harus ditingkatkan, hal ini sejalan dengan keberhasilan terapi yang nanti akan dijalani ketika mereka menerima obat. Masyarakat ketika menerima obat di apotik atau rumah sakit mereka cenderung tidak ingin menggali informasi lebih mengenai obat yang mereka terima, mereka hanya mendapatkan informasi satu arah dari apoteker yang memberikan obat. Kegiatan Pengabdian Masyarakat ini bertujuan untuk meningkatkan keingintahuan masyarakat terhadap informasi obat yang diterima sehingga penggunaan obat tersebut dapat optimal karena digunakan dengan baik dan benar. Pengabdian ini dilakukan di Puskesmas Babakan Madang, terhadap pasien yang nantinya akan menerima obat. Metode yang dilakukan adalah melakukan penyuluhan mengenai pentingnya mengenal obat yang akan mereka minum nanti, sebelum dilakukan penyuluhan, dilakukan pre test terlebih dahulu untuk menilai seberapa besar keingintahuan masyarakat terhadap penggunaan obat yang baik dan benar. Setelah penyuluhan diberikan dilakukan post test dengan soal yang sama. Hasil dari kegiatan ini adalah terdapat peningkatan pengetahuan pada 79\% Pasien. Diharapkan dengan adanya peningkatan keingintahuan masyarakat mengenai penggunaan obat yang baik dan benar, dapat membantu mengurangi kasus penggunaan obat yang tidak benar dan terapi obat yang salah, sehingga kesehatan masyarakat dapat meningkat. Dalam kegiatan ini juga dilakukan pemeriksaan kesehatan gratis meliputi pemeriksaan tekanan darah dan kadar gula darah.
\end{abstract}

Kata kunci: Peningkatan Keingintahuan; Masyarakat; Penggunaan Obat

ABSTRACT. The desire of the community to find out how to use good and right drugs at this time must be improved, this is in line with the success of the therapy which will be followed when they receive the medicine. When people receive drugs at a pharmacy or hospital they tend not to want to dig up more information about the drugs they receive, they only get one-way information from the pharmacist who provides the medicine. The Community Service activity aims to increase the public's curiosity about the information received by the drug so that the use of the drug can be optimized because it is used properly and correctly. This service is done at Babakan Madang Health Center, for patients who will later receive the drug. The method is to conduct counseling on the importance of recognizing the drugs they are going to consume later, before the counseling is conducted, a pre-test is conducted first to assess how much the public's curiosity about the use of drugs is good and right. After counseling was given a post test with the same questions. The results of this activity were an increase knowledge in $79 \%$ of patients. It is hoped that by increasing the public's curiosity regarding the use of good and right medicine, it can help reduce improper drug use cases and wrong drug therapy, so that public health can increase. In this activity including a free medical check-up included blood pressure checks and blood sugar levels.

Key words: Increased Curiosity; Society; Good and Right Drug Use.

\section{PENDAHULUAN}

Kesehatan merupakan bagian terpenting dari kesejahteraan Masyarakat. Pembangunan kesehatan merupakan salah satu upaya dari pembangunan nasional yang diselenggarakan disemua bidang kehidupan. Tujuan pembangunan kesehatan adalah tercapainya hidup sehat bagi setiap Masyarakat, serta untuk mewujudkan derajat kesehatan yang optimal. Dengan berkembangnya ilmu pengetahuan dalam dunia kesehatan dewasa ini, memahami dan mengetahui peng-gunaan obat yang baik dan benar merupakan bagian penting dari tercapainya kesehatan Masyarakat. Kesehatan juga merupakan salah satu kebutuhan dasar manusia, disamping sandang, pangan dan papan. Maka dianggap perlu Masyarakat mengetahui hal-hal penting apa saja terkait obat yang diterimanya, dimulai dari bagaimana cara mendapatkannya, menggunakannya, menyimpannya dan membuangnya.

Mewujudkan derajat kesehatan di masyarakat peranan obat sangatlah penting, karena obat merupakan salah satu faktor yang berpengaruh dalam penyembuhan suatu penyakit. Tujuan diberikan Obat adalah untuk mendiagnosis, mengurangi rasa sakit, mengobati, dan mencegah penyakit. Obat dapat menyembuhkan, namun obat dapat juga menyebabkan keracunan bahkan kematian jika tidak digunakan sesuai dosis. Oleh karena itu, obat dapat menyembuhkan apabila digunakan dengan tepat, baik dosis maupun waktunya. Jika obat digunakan dalam dosis berlebihan dapat menimbulkan keracunan, sedangkan jika dosisnya kurang maka tidak dapat menyembuhkan. Masyarakat harus benar-benar paham dalam memilih, menggunakan, menyimpan obat sebagai upaya pengobatan sendiri lalu kemudian membuang sisa obat dengan benar agar tidak disalahgunakan. Peran Farmasis untuk memberikan informasi selengkapnya mengenai obat yang didapatkan masyarakat sangatlah penting agar tercapainya tujuan pengobatan yaitu kesembuhan.

Sebagian besar Masyarakat yang menderita sakit akan melakukan usaha untuk menghilangkan atau mengurangi rasa sakit yang dideritanya. Tidak sedikit orang yang gagal melakukan usaha penyembuhan tersebut dalam 
mematuhi prosedur terapi yang disarankan dokter dan farmasis, sehingga berakibat pada kegagalan terapimaupun timbulnya efek samping yang lebih membahayakan. Perilaku ketidakpatuhan Masyarakat dalam proses terapi pada umumnya terkait dengan aturan pemakaian obat, baik yang menggunakan resep dokter maupun obat bebas yang dibeli di apotek atau toko obat. Penyebabnya ketidakpatuhan yaitu adanya ketidakpahaman terhadap aturan minum obat dan cara meminum obat. Pasien dikatakan patuh bila membeli seluruh obat, memakan obat tepat waktu, memakan sesuai anjuran dokter. Dan dikatakan tidak patuh bila tidak meminum obatnya dengan teratur, atau tidak menghabiskan dalam waktu yang diberikan sesuai anjuran dokter.

\section{METODE}

Kegiatan PKM ini dilaksanakan di Puskesmas Babakan Madang Kabupaten Bogor. Pelaksanaan kegiatan ini dilakukan untuk mendapatkan hasil yang menunjukan adanya persentase Peningkatan Keingintahuan Masyarakat Mengenai Penggunaan Obat yang Baik Dan Benar. Sebelum Masyarakat diberikan Penyuluhan, Masyarakat mengisi angket (sebelum penyuluhan) angket berisi tentang pertanyaan seputar penggunaan obat ( $\mathrm{DaGuSiBu})$. Setelah Masyarakat mengisi angket kemudian diberikan penyuluhan mengenai Penggunaan Obat yang baik dan Benar dan kemudian setelahnya diberikan kembali angket yang sama untuk diisi apakah jawaban pada angket masih sama seperti sebelum diberikan penyuluhan atau tidak. Setelah pengisian angket selesai, Masyarakat diberikan kesempatan untuk pemeriksaan kesehatan meliputi pengukuran tekanan darah, gula darah serta konsultasi kesehatan meliputi obat yang didapatkan setelah berobat.

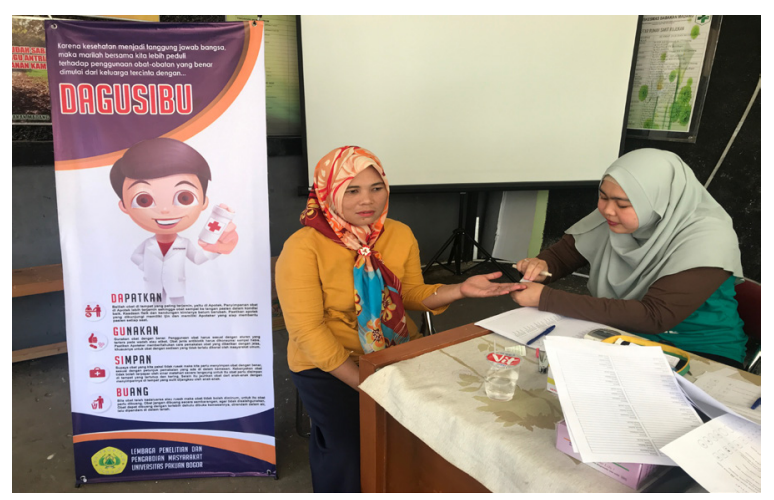

Gambar 2. Pemeriksaan Kesehatan Gratis

Setelah Masyarakat mengisi angket kemudian dilakukan penyuluhan mengenai Penggunaan Obat yang Baik dan Benar. Setelah selesai diberikan penyuluhan Masyarakat mengisi angket yang sama dengan menjawab dikolom (setelah penyuluhan). Sehingga terlihat ada tidaknya Peningkatan Keingintahuan Masyarakat Mengenai Penggunaan Obat yang Baik Dan Benar.

Setelah kegiatan penyuluhan selesai dilaksanakan kegiatan pemeriksaan kesehatan gratis meliputi pemeriksaan tekanan darah dan kadar gula darah, didapatkan 50\% dari pasien memiliki tekanan darah diatas normal dan hampir semua pasien tidak menyadari memiliki tekanan darah diatas normal. Bagi Pasien yang memiliki kadar tekanan darah diatas normal kami menyarankan untuk mengkonsultasikan selanjutnya kepada dokter.

\section{HASIL DAN PEMBAHASAN}

Kegiatan Pengabdian Kepada Masyarakat yang berjudul Upaya Peningkatan Keingintahuan Masyarakat Mengenai Penggunaan Obat yang Baik dan Benar di Puskesmas Babakan Madang Kabupaten Bogor, ditujukan untuk meningkatkan pengetahuan Masyarakat mengenai penggunaan obat yang baik dan benar sehingga tercapai tujuan terapi yaitu kesembuhan. Kegiatan ini juga membuka wawasan Masyarakat yang awalnya tidak mengetahui cara meminum obat yang benar menjadi lebih memahami sehingga mengurangi tingkat penggunaan obat yang tidak benar. Kegiatan ini diikuti oleh 24 Masyarakat yang semuanya adalah pasien pada Puskemas Babakan Madang yang telah menerima resep obat. Terdiri dari 19 Pasien Wanita dan 5 Pasien Pria.

\section{Hasil Analisis Angket Peningkatan Pengetahuan}

Kegiatan Pengabdian ini diikuti oleh 24 Orang yang semuanya adalah pasien pada Puskemas Babakan Madang yang telah menerima resep obat. Terdiri dari 19 Pasien Wanita dan 5 Pasien Pria. Setelah dilakukan penyuluhan, Pasien melakukan konsultasi terkait obat yang didapat meliputi aturan pakai dan waktu meminum obat. Berdasarkan pertanyaan angket yang terdiri dari 10 soal didapatkan analisis grafik sebagai berikut :

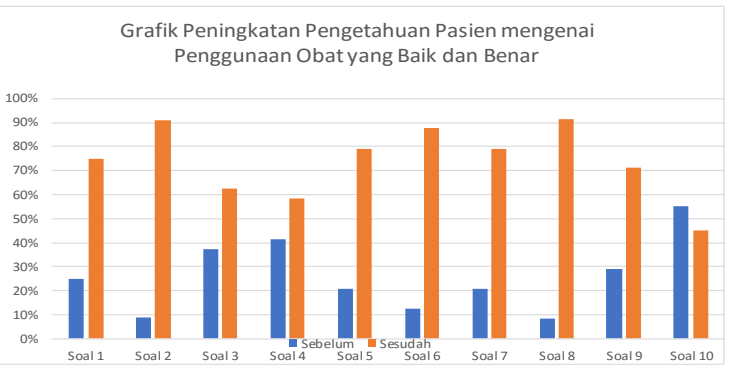

Dari hasil angket setelah penyuluhan diketahui bahwa 25\% Pasien masih belum mengetahui bahwa membeli obat harus di apotik atau toko obat yang memiliki apoteker penanggung jawab. 91\% Pasien sudah memahami bahwa ketika membeli obat harus melihat apakah obat tersebut sudah memiliki izin edar obat. Masih ada 37,3\% Pasien yang belum memahami bahwa obat keras harus dibeli dengan resep dokter. 41,66\% Pasien masih belum mengerti bahwa jika mendapatkan resep Antibiotik maka obat tersebut harus dihabiskan. 79\% Pasien sudah mengetahui aturan pakai obat jika diminta $3 x$ sehari artinya obat tersebut diminum setiap 8 jam, atau jika diminta 2x sehari artinya obat tersebut diminum setiap 12 jam. Sudah ada 87,5\% Pasien yang mengerti bahwa dilarang mengkonsumsi 
obat yang sama dengan keluarga atau kerabat jika gejala penyakit sama tanpa berkonsultasi dengan dokter. Masih ada 20,8\% Pasien yang belum mengetahui bahwa label pada kemasan obat sebaiknya tidak dilepas karena merupakan identitas obat dan banyak informasi penting yang ada padanya seperti tanggal kadaluarsa. 91,6\% Pasien memahami bahwa obat yang sudah kadaluarsa tidak boleh diminum lagi karena berbahaya, bisa jadi obat sudah rusak dan dapat menyebabkan keracunan. Masih ada 29\% Pasien yang belum mengerti bahwa membuang sisa obat tidak boleh sembarangan karena dapat disalahgunakan orang yang tidak bertanggung jawab. Masih ada 55\% Masyarakat yang masih belum memahami cara membuang sisa obat yang benar. Dari hasil keseluruhan terjadi peningkatan pengetahuan pasien terhadap penggunaan obat yang baik dan benar dengan presentase $79 \%$.

\section{SIMPULAN}

Telah Terjadi Peningkatan Keingintahuan Masyarakat Mengenai Penggunaan Obat Yang Baik Dan Benar sebesar 79\% dari total 24 Pasien dengan nilai rata-rata 81. Kendala yang dihadapi saat kegiatan PKM ini adalah ketika kami harus menyampaikan materi penyuluhan kepada pasien yang kondisi (sakit) berbeda antara pasien satu dengan yang lain sehingga menjadikan pemahaman yang diterima tiap pasien dapat berbeda. Hal ini diperjelas dengan hasil pengisian angket, masih ada 21\% Pasien yang belum mengalami Peningkatan Keingintahuan Masyarakat Mengenai Penggunaan Obat Yang Baik Dan Benar.

Kegiatan PKM ini sudah memberikan manfaat bagi Pasien terhadap penggunaan obat yang baik dan benar. Penggunaan terhadap obat yang mereka terima untuk pengobatan sendiri di rumah. Oleh karena itu adanya Peningkatan Keingintahuan Masyarakat Mengenai Penggunaan Obat Yang Baik Dan Benar menjelaskan bahwa masih perlunya dilakukan penyuluhan mengenai obat khususnya mengenai cara memusnahkan sisa obat yang baik dan benar, mengingat masih banyak Masyarakat yang membuang sisa obat yang sudah rusak atau kadaluarsa secara sembarangan sehingga dapat memancing orang untuk melakukan kejahatan.

\section{UCAPAN TERIMA KASIH}

Ucapan terima kasih penulis tujukan kepada semua pihak yang membantu dalam menyukseskan kegiatan pengabdian masyarakat ini. Terima kasih penulis tujukan kepada Tim PKM Rini Ambarwati, M.Si, Apt dan Emy Oktaviani, M.Clin, Apt yang telah bekerjasama dengan baik sehingga kegiatan ini berjalan dengan sukses. Ketua LPPM Universitas Pakuan Dr Henny Suharyati, M.Si yang telah memberikan dana hibah PKM sehingga kegiatan PKM ini dapat terwujud. Terima kasih juga peneliti sampaikan kepada Kepala Puskesmas Babakan Madang dr. Desy Pondang yang telah memberikan waktu dan tempat untuk kami menyelenggarakan kegiatan PKM ini, serta kepada pasien yang telah ikut berpartisipasi dalam kegiatan PKM ini.

\section{DAFTAR PUSTAKA}

Depkes RI, 2008. Materi Pelatihan Peningkatan Pengetahuan Dan Keterampilan Memilih Obat Bagi Tenaga Kesehatan. Departemen Kesehatan RI. Jakarta.

DepkesRI, 2011. Penggunaan Obat Rasional. Departemen Kesehatan RI. Jakarta.

Depkes RI, 2011. Peraturan Menteri Kesehatan Republik Indonesia Nomor 2406/Menkes/Per/ XII/2011 Tentang Pedoman Umum Penggunaan Aantibiotik. Departemen Kesehatan RI. Jakarta.

Gitawati R.,2009. Interaksi obat dan beberapa Implikasinya. Media Litbang Kesehatan, 18(4):175-183

Hakim, L, 2012. Farmakokinetik Klinik. Bursa Ilmu, Universitas Gadjah Mada. Yokyakarta.

Lexi Comp. 2016. Drug Information Hand book. 25 $5^{\text {th }}$ Edition. Publisher Lexi-Com Inc

Maulana A,.2016. Health. Tribun Jaya. 7 Agustus. Hal.13 